Published as: Bazuin, S., Azadi, H., Witlox, F. (2011), Application of GM

Crops in Sub-Saharan Africa: Lessons Learned from Green Revolution.

Biotechnology Advances, vol. 29 (2011), 908-912.

\title{
Application of GM Crops in Sub-Saharan Africa: \\ Lessons Learned from Green Revolution
}

\author{
Sjoerd Bazuin ${ }^{\mathrm{a}}$, Hossein Azadi ${ }^{\mathrm{b} 1}$, Frank Witlox $^{\mathrm{b}}$ \\ ${ }^{a}$ Faculty of Geosciences, Utrecht University, The Netherlands \\ ${ }^{b}$ Department of Geography, Ghent University, Belgium
}

\begin{abstract}
While the Green Revolution has been successful in some regions like South and East Asia, it could hardly address any achievement in Sub-Saharan Africa (SSA). This paper tries to draw a picture on lessons learned from the failures of this revolution that should be taken into account before implementing the so-called Gene Revolution in the SSA region. After scrutinizing the failures and the pros and cons of GM crops in the region, the paper introduces some potentials for improving the malnutrition situation in SSA through launching a successful GM technology. However, it remains doubtful whether this technology can improve the situation of small-scale farmers as long as they receive no financial support from their national governments. Therefore, before any intervention, the socio-economic and environmental impacts of GM technology need to be carefully addressed in the framework of a series of risk assessment studies. Besides, some sort of multi-stakeholder dialogue (from small-scale farmers to consumers) involving public-private sector and non-governmental organizations should be heated up at both national and regional levels with regard to the myths and truths of this technology.
\end{abstract}

Keywords: Gene Revolution, food security, undernourishment, small-scale farmers, population growth.

\section{Introduction}

\footnotetext{
${ }^{1}$ Corresponding author. Email: hossein.azadi@ugent.be, Tel. +32 (0)9 2644695 . Fax +32 (0)9 2644985.
} 
This paper discusses the consequences of genetic modified (GM) crops in Sub-Saharan Africa (SSA) compared with the Green Revolution. It is a critical issue because while the Green Revolution brought much success in some regions like South and East Asia, it could never work out in the SSA region (Mugabe, 2003). At the moment, this is an important topic due to the fact that still millions of hungers live in this region and deal with poverty. According to the FAO (2009), in 2005, 213.8 millions of poor were identified as undernourished in SSA. Moreover, more than 600 million people live on small farms measuring no more than a few hectares each in this region where low productivity due to biotic and abiotic factors is responsible for food insufficiency and malnutrition (Olembo, 2005 ; 173). It seems that without a new revolution in the agricultural sector, their living standards might be worsened. A couple of important questions could be asked here: why did not the Green Revolution work out in SSA? And what can be learned from this revolution to launch a successful and new revolution called 'Gene Revolution' in this region?

More precisely, the paper tries to answer to the following questions: Why was not the Green Revolution successful in SSA? Can the Gene Revolution result in an improvement on the malnutrition in the region? What can be learned from the failure of the Green Revolution in SSA to benefit from a successful GM technology approach? What are the main advantages of GM crops compared with non-GM's in SSA? What threats are involved in when implementing GM technology in the region?

\section{Green Revolution}

\subsection{Successor}

In 1798, Thomas Malthus published his first Essay on the Principle of Population. He believed "the populations of the world would increase in geometric proportions while the food resources available would increase only in arithmetic proportions". Malthus rejected that technological progress might deal with the growing population (Weeks, 2005). When the industrial revolution emerged, the food production passed the population growth. However, despite the increased food production since 150 years ago, there are still enormous undernourishment problems. The problems prompted the Rockefeller Foundation, in the 1940 's, to gather and fund a team of specialists in order to develop agricultural innovations 
for developing countries (Wu \& Butz, 2004). The team developed some new seeds which were superior to other indigenous species in terms of increasing the yield, yield stability, resistant to diseases and insects and grain quality. Along the seeds, they also introduced a package of other innovations including new fertilizers, irrigation systems, and pesticides (Perkins, 1990). According to Wu \& Butz (2004), a new version of Green Revolution is now emerging as so-called 'Gene Revolution'. The supporters of the Gene Revolution argue that this revolution can create resistant plants to certain diseases and water shortages, and even capable to improve soil texture. On the contrary, the opponents believe the new revolution may bring unexpected and irreversible effects to human health and environment (Knox \& Marston, 2007).

\subsection{Success and failure}

During the Green Revolution, the improved high yield varieties (HYVs) resulted in a tremendous increase in food production worldwide. They accounted for almost 90 and 70 percent of the increased world's foods, respectively at the end of the 1960s and 1970s (Knox \& Marston, 2007). The Green Revolution was especially an obvious success in Asia and Latin America where the regions could almost eliminate the undernourishment. However, the revolution did not have the desired results everywhere. It did not have its intended effects in SSA and even at the moment, the results in most of the African countries are limited. While the new technologies were performing well in laboratories, they were not successful in the field. The researchers ignored the local conditions of these countries (Wu \& Butz, 2004). The scientists had also not taken into account the fact that many of the existing crops have several secondary uses like fuel, provision of hay, building materials and fodder. The new developed crops did not provide the farmers such secondary functions, which discouraged them from employing the new technologies (Smirzai, 2005). Instead, the revolution has led to a monoculture by cultivating a minimum variety of some cereals like maize, wheat, and rice (Thompson, 2007).

Also, the low population density in the SSA region hampered the application of new seeds, fertilizers and pesticides in order to intensify agriculture (Smirzai, 2005). When rapid population growth occurred in those countries which have low population density, the farmers continued using extensive methods of agriculture because there was still uncultivated 
land available. They were not forced by land scarcity to apply new techniques and therefore the farmers did not make the transition to intensification of agriculture. On the one hand, the rapid population growth, and on the other, extensive agricultural practices (Smirzai (2005) resulted in a futile circle as the practices could result in agricultural land conversion (Azadi et al., 2010) and lower agricultural output.

The application of fertilizers was another important factor in order to let the new varieties become more productive (Otsuka \& Kalirajan, 2006). However, because of the high fertilizers costs and low outputs prices, the Sub-Saharan African peasants were discouraged from using the fertilizers. As a result, the soil fertility tended to deplete and the outputs seemed to decrease. Otsuka and Kalirjan (2006) argue that the high fertilizers' costs weakened the peasants' bargaining power at market level. Furthermore, the prices increased because of the transportation system in SSA that was not well developed. Wu \& Butz (2004) discuss, because of undeveloped transportation systems, it was difficult to put modern technologies timely in places where needed. Besides fertilizers, chemical pesticides were also required. Obviously, over time, pesticides and fertilizers could cause soil degradation and water pollution. In sum, the following reasons can be considered for the failures of the Green Revolution in SSA:

- While implementing new agricultural techniques, the hidden functions of conventional crops were neglected by researchers;

- Low population density and abundance of uncultivated land did not force farmers to apply new techniques. Such drivers let farmers continue their extensive agricultural practices.

- The high fertilizers' costs and low outputs prices concerned peasants about implementing the new techniques;

- An undeveloped transportation system hampered a fair distribution of the modern technologies among the farmers;

- The risk to human health and environmental pollution due to the use of fertilizers and pesticides, discouraged the farmers from going for the new varieties. 


\section{Toward the Gene Revolution: lessons learned from the Green Revolution}

There are a lot of similarities between the two revolutions. The Green Revolution increased food production that was very vital for developing countries because of their serious food deficiency. At the moment, the Gene Revolution has the potential to increase food production as well (Wu \& Butz, 2004). The technology of both the revolutions focuses on plant attributes and they both concentrate on the global markets and capture subsistence farming. Because of such similarities, the following issues should carefully be addressed in the framework of a series of risk assessment case studies before welcoming the GM technology.

First, the costs and charges of GM technology should be addressed. At the moment, such technologies are being supported by major oligopoly capitalist firms like Monsanto, Pioneer Hybrid, Syngenta, and Dupont which are playing the important role of disseminating GM seeds throughout the world. GM products may be licensed by the patent holders and therefore, those farmers who grow GM crops might become dependent on buying their seeds from those, relatively few suppliers (Morse, 2008) while the seeds have to be bought every year because farmers cannot reproduce them by themselves. Furthermore, according to (McMichael, 2009a:252), at a time when flexible seed selection by African farmers has managed recurring drought, gene patents threaten farmer sovereignty, and shift resources away from farmer-based strategies for climate change survival and adaptation.

At present, many SSA farmers are unable to compete with the relatively lower prices that many especially North American food producers are able to sell rice, wheat, corn and soybeans for and the consequence has been a ruination of many SSA farmers who wind up flooding the major cities of Africa. More importantly, "small-scale farmers" cannot easily afford such new expensive seeds each year. Just like the HYVs, GM seeds are a large expenditure for such farmers in SSA (Wu \& Butz, 2004).

There are also concerns about possible dumping (i.e. setting the pricing of a product below its cost of production) of GM crops by the firms or nations in an effort to dispose of surplus stocks or to recoup money spent on costly transgenic research and development (Azadi et al., 2011). In 2003, for instance, the United States had 65 million tons of surplus non-GM wheat and rice in its Food Cooperation stocks. Paradoxically, just a year before, the US sent India a large shipment of food aid with genetically modified ingredients, which India rejected (Friends of the Earth International, 2003). The US has also dumped subsidized rice in Haiti, 
forcing thousands of poor rice farmers off the land (Kamau, 2002). Dumping food on to poorer nations (i.e. free, subsidized, or cheap food, below market prices) undercuts local farmers, who cannot compete and are driven out of jobs and into poverty, further slanting the market share of the larger producers such as those from the US and Europe (Shah, 2005).

Accordingly, the State has been accused of dumping some GM crops, especially into francophone parts of Africa, in part because Europe does not accept it. This might even undercut local producers accelerating the rural to urban shift. The concern has also been that single seed companies may gain a monopoly over the seed supply market. If this happens, prices could be increased all the way up to the consumer because of increased seed prices.

Also, the risk of widening the gap between large and small-scale farmers should be addressed. Rich farmers might be able to adopt GM crops earlier and faster than the farmers (Smirzai, 2005). Accordingly, if GM crops become available in SSA, they will be more available to wealthier farmers who can afford such technological innovations (Azadi et al., 2011). Therefore, a first lesson learned might be to give the poor farmers easier access to credits (e.g.) by subsidies and low interests loans. However, others allege a biotechnological bias toward larger farms, because the society can have some earlier benefits through them (Azadi and Ho, 2010). As a result, it may solve the problem of per capita food insecurity in SSA countries.

Second, the dissemination of biotechnology knowledge among the SSA region remains poor. Even though the undeveloped infrastructure (roads, communication systems) hamper the spreading of biotechnological knowledge, GM producers should strive for spreading GM crops throughout the whole SSA region, instead of limiting the access to biotechnologies to a small number of (large-scale) farmers. For instance, in Asia, the first Green Revolution varieties became regional public goods, in the sense that varieties were diffused in the country where they were being developed, as well as in neighboring regions (Otsuka \& Kalirjan, 2006). If there is no openness in the production methods of GM crops in different sub-regions of SSA, chances to generate the Gene "Revolution" are not high. Hence, a more favorable environment for implementing GM technology in SSA may arise when the relatively few suppliers of GM seeds, agricultural research centers, large, and small-scale farmers establish longstanding relationships in order to exchange knowledge about a feasible implementation of GM crops. However, as long as the knowledge of biotechnology is 
privatized by the use of patent rights and a monopoly of a few GM seeds suppliers, such a favorable environment cannot be created.

Third, the investments in infrastructures (e.g. transport systems, communication systems) have to be made to attain more access to markets and to create an encouraging environment to disseminate the biotechnology knowledge among participating stakeholders. Without necessary improvements in infrastructures, the Gene Revolution may experience the same failures as its predecessor.

Carruthers et al. (2010) discuss when infrastructure is absent or degraded, it no longer fulfills its connective functions, and the economy suffers. Although investments in infrastructure have currently contributed more than half to Africa's improved economic growth, still much more needs to be made (Prasad, 2011). According to IFC (2010), in recent years, investments in the SSA's infrastructures have averaged about $\$ 10$ billion per year, equivalent to just three percent of the region's gross domestic product and only approximately half of what is needed to support sustained economic growth.

The African leaders of the New Partnership for Africa's Development (NEPAD) have clearly indicated that among their priorities are infrastructure and agriculture; the two have an interface. To launch a widespread agricultural development program (like the Gene Revolution), NEPAD discusses the necessity of major transport corridors for products processing and marketing (FAO, 2002), especially, if products are expected to be presented beyond local markets (Azadi et al., 2011). As a response to this problem, national governments together with international donors could primarily focus on improving existing major corridors and constructing roads between farms and markets to increase the linkage between producers and consumers (MIT, 2011).

Fourth and final is that despite an increase in food production, there are a lot of political, socio-economic and bio-physical interplays that should also be considered. For example, McMichael (2009a,b) draws a historical picture on geo-political drivers in the framework of global ecology and a "food regime analysis". He presents a macro analysis to explain the strategic role of major previous agricultural programs (like the Green Revolution) in the construction of the world capitalist economy (McMichael, 2009b). He further discusses (McMichael, 2009a) that the global development project faces newly evident challenges in the combination of energy, climate and food crises which are realized more critical in SSA 
and can affect major new food policies (like the Gene Revolution) in favor of capitalist economy resulting more in marginalizing poor farmers (Saini, 1976; Wu \& Butz, 2004), and biodiversity loss (Goodland, 1997; Trewavas, 2001). As a result, if such incidental circumstances are not taken into account, it will be difficult to launch a successful Gene Revolution.

\section{Application of GM crops in Sub-Saharan Africa}

\subsection{Potential gains}

There are some potential gains when implementing GM crops in SSA. First and most importantly, those farmers who use GM crops might gain higher yields that could provide the basis to lessen the undernourished (Smirzai, 2005). At the moment, SSA is dependent on wheat and rice imports to acquire sufficient food for its population. Between 1995 and 2001, rice consumption increased by 5.3 percent, while the production rate grew by 2 percent (FAO, 2008). To meet the high demands, the rice imports increased annually by 8.4 percent so that SSA now accounts for 20 percent of the total world rice imports. If GM rice is implemented more extensively throughout SSA, this rice can be adapted to the specific environmental circumstances in the region, and as a result, dependency on imports can decrease. However, policy makers need to bear in mind the importance of food distribution. This view has been theorized by Drèze and Sen's (1990) entitled approach in which they elucidate that starvation is not necessarily caused by an overall shortage of food. Not everybody has the same capacities, capabilities, and connections to get access to food. Hence, if yields increase due to the application of GM seeds, it does not necessary mean that undernourishment will decrease. It is also important to understand how the farmers sell and distribute their products.

Second, with regard to plant improvement, according to Morse (2008), GM crops are more targeted than conventional crops. For GM crops breeding, it is not necessary to handle millions of genes but only a few (Morse, 2008). Some other potential gains of the implementation of GM crops in SSA are presented by Thomson's (2007) study on some practical examples of the implementation of insect resistant maize varieties, drought tolerant, and virus resistant crops. The advantages presented include maize genes that can be modified 
to specific situations, as in this case, they were modified to become more resistant to viruses, insects, and also to the African dry weather. Furthermore, the small-scale farmers in SSA can use such insect resistant varieties to protect their crops against fungal infections which are originated mostly from the moist and warm storages of the crops in this region.

Third is the possibility to provide a tolerance to herbicides. This means that a farmer can spread herbicide on his/her field in order to eliminate undesirable plants except those which carry the tolerant gene (Wu \& Butz, 2004). For consumers, GM crops can have some indirect advantages too. When farmers adopt GM crops, the costs of cultivating such crops might decrease due to less chemical inputs, because of the pest resistance of some GM crops with transgenic pesticides (Azadi \& Ho, 2010). As a result, food prices could decrease, so the possibilities for the SSA's poor people to be fed may increase. Furthermore, there are some developments with crops enrichment by adjusting nutritional elements. Perhaps, the most famous enrichment is used for 'golden rice'. The rice contains some extra vitamin A which can protect people from blindness (Anderson \& Jackson, 2005). As, according to Mason et al. (2001), 30 to 40 percent of preschool children in SSA suffer from vitamin A deficiency (VAD), the attachment of specific nutrients by GM technologies might partly be beneficiary to solve the deficiency of micronutrients in this region.

\subsection{Potential losses}

Critics argue that there are several limitations when using GM crops in SSA. First, opponents fear that GM crops can cause a loss in the genetic diversity of SSA, because the farmers will rely on producing a fixed set of GM crops. Consequently, without genetic diversity, the risk of epidemics will increase (Smirzai, 2005). Moreover, a loss in genetic diversity can exacerbate soil degradation that tends to be more deteriorated due to the loss of microorganisms which naturally replenish the soil nutrients. Van Straaten (2002) argues that the African soil productivity has steadily declined in the last two decades due to the high depletion rate of the soil. Without maintaining a fertile soil, the success rate for the SubSaharan African farmers to produce sufficient and safe food will not be high. However, there are some signs that GM crops could potentially be a way of enriching soil texture since crops engineered are prospered not only to face drought, disease, and pests, but also to offer greater biomass post harvest. Due to the huge fertility issues affecting so much of Africa's latosol 
soils, more immediate advantage may accrue to SSA by simply breaking up and spreading the crushed remains of rocks that are badly needed minerals contained in those rocks like phosphorus.

Second, critics fear a potential risk for gene transfer from one GM to other non-GM crops. According to Altieri (2005), it is self-evident that modified genes can move beyond the intended destinations and easily contaminate other proximate non-GM crops. This crosspollination/contamination may cause serious problems for the non-GM crop growers since GM traits in cash crops, specifically for export markets in Europe are unacceptable (Anderson \& Jackson, 2005). The EU is not allowing GM crops for human use, because according to the union, it may endanger human health. The EU's politicians want to make sure that they import totally GM free products. This means that if Sub-Saharan African countries need to open a market in the EU, they may not deal with GM crops. However, Anderson and Jackson (2005), after executing the scenario simulation model GTAP (Global Trade Analysis Project), suppose that SSA gains more welfare by allowing GM production in their countries instead of banning such products in order to attain a greater access to the EU market. Also Paarlberg (2006) argues that the risks of commercial export for Africa are realistic but low. After analyzing the data of more than 12 African countries, he claims that the contribution of GM products to the total farm exports is not significant while only a small share of these GM products may go to sensitive GM markets such as the EU's.

Third, also related to the risk of cross-contamination, is the possibility of evolving 'super weeds'. Transgenes might escape from GM crops to wild species and create the so-called super weeds, which are resistant to herbicides (Morse, 2008). It might result in useless implementation of costly herbicides which are often too expensive for the poor farmers in SSA.

Fourth, the last important constraint is that GM technology might not reach the poor farmers due to the property and rights of the technologies (Azadi \& Ho, 2010). In line with this constraint, Amalu (2003) has also stated that profits of new advanced crops will probably benefit large rather than small-scale farmers who have usually less access to financial resources and awareness towards technological advances. The adoption and adaption of GM technology by the Sub-Saharan African farmers might also be constrained by high illiteracy 
rates that result in difficulties to disperse knowledge and awareness among the farmers to employ the technology.

\section{Discussion and conclusion}

Although the global food crisis during 2007-2008 was sunk into oblivion by the emergence of the financial and economic crisis, the need for feeding the ever increasing population can never be ignored. Whereas SSA includes a large part of the growing world population, the access and availability to sufficient nourishment still remains very scarce in the region. While GM crops have been introduced in South Africa, Malawi and a few other southern SSA countries, their introduction has been sporadic and they might be no panacea for solving food insecurity. To better understand the possible gains and losses of GM crops in SSA, it is imperative to take into account the failures of the Green Revolution in the SSA region. After scrutinizing the failures and also the pros and cons of GM crops in this region, this paper considers some potentials for improving the malnutrition situation in SSA through launching a successful Gene Revolution.

Drought tolerant GM crops could be beneficiary for this region where chronic and acute droughts often occur. The big GM crop companies (Monsanto and Pioneer Hybrid, Syngenta, and DuPont) have already developed crops with drought tolerance traits. Accordingly, the Sub-Sahara African farmers can therefore rest assured of a safe-net harvest when facing drought (Paarlberg, 2006). However, without financial support from the African states, the small-scale farmers will not be able to afford such an expensive technology. For example, in Ethiopia more than 90 percent of the agricultural outputs are produced by subsistence farmers (Azadi et al., 2011). If they cannot get access to the aforementioned drought tolerant crops, the implementation of GM crops will not have a significant impact on the region. Furthermore, biotechnology allows also for breeding the varieties which are enriched by micronutrients such as vitamin A, zinc, and iron. Crops enriched with micronutrients can be provided to the malnourished people in SSA who often have to deal with an unbalanced diet (von Braun, 2010). In addition, GM crops have a lower demand for herbicides and pesticides which can result in less cost for the farmers and positive environmental impacts.

In conclusion, despite the potential advantages of GM technology in SSA, it remains doubtful whether it can positively affect the situation of small-scale farmers as long as they receive no financial support from their national governments. Moreover, the local socio-economic and 
environmental impacts of GM crops need to be considered. When GM crops contaminate non-GM's, conventional breeders face the risk of diminishing exports. Hence, the effects of implementing GM technologies in SSA on their export markets should critically be assessed before launching any Gene Revolution as a solution for malnutrition in SSA. Also the environmental impacts should carefully be addressed. In order to be fully aware of the positive and negative impacts of GM technology in SSA, von Braun (2010) recommends an increase of investments in $R \& D$ and a strengthening of partnerships to exchange biotechnology knowledge between organizations at different scales (global, national, regional, and local).

In addition, it should be noted that given some important contextual differences, existing GM researches will not necessarily be transportable to SSA. The main contextual differences include possible dissimilarities in the roots of food insecurity and malnutrition in the region, the nature of health concerns, the prominence of agriculture, and diverse food regulation systems (Mugabe, 2003; Pelletier, 2005). This may imply that the potential benefits as well as the potential risks of biotechnological innovation may have disproportionate impacts in the SSA context that should explicitly be addressed. For instance, corn and soybeans that are glyphosate resistant in North American must locally be tested through many parts of SSA before their seeds are sold directly to farmers. Such adaptability researches must study the biosafety and environmental risk assessment concerns that have been raised around the world in response to GM crops before these crops can safely be promoted. Overall, all the impacts of using this technology should carefully be assessed in the framework of a series of risk assessment studies on the bases of both "crop-case" and "region-case".

The risk assessment studies should address the possible trade-offs; most importantly, biosafety regulatory frameworks, the role of multi-national companies and other stakeholders in the application of biotechnology with respect to biosafety issues (Ushewokunze-Obatolu, 2005), regulatory policies that warrant the right of poor farmers and consumers (Pelletier, 2005), the role of intellectual property right (Olembo, 2005), and the gains and losses of stakeholders (Matz and Ferenz, 2005).

Lastly, some sort of multi-stakeholder dialogue involving public-private sector and nongovernmental organizations (NGOs) should be heated up at both national and regional levels. Some people within Africa especially believe that implementing GM technology goes against 
nature and God. Others claim huge productivity benefits with minimal negative environmental consequences of implementing this technology. Hence, the academic disputes on the potential of GM technology need to be widened to a broader public debate in which all stakeholders (from small-scale farmers to consumers) can get informed about all the myths and truths of this technology.

\section{References}

Altieri MA. The myth of coexistence: why transgenic crops are not compatible with agroecologically based systems of production. Bulletin of Science, Technology \& Society 2005;25(4):361-371.

Amalu UC. Plant biotechnology and food crop development in Sub-Saharan Africa. Technology in Society 2003;26(4):537-550.

Anderson K, Jackson, LA. Some implications of GM food technology policies for SubSaharan Africa. Journal of African Economies 2005;14(3):385-410.

Azadi H, Ho P. Genetically modified and organic crops in developing countries: a review of options for food security. Biotechnology Advances 2010;28(1):160-168.

Azadi H, Ho P, Hasfiati L. Agricultural land conversion drivers: a comparison between less developed, developing and developed countries. Land Degradation \& Development 2010; DOI: 10.1002/ldr.1037.

Azadi H, Talsma N, Ho P, Zarafshani K. GM crops in Ethiopia: a realistic way to increase agricultural performance? Trends in Biotechnology 2011;29(1):6-8.

Carruthers R, Krishnamani RR, Murray S. Investing in transport infrastructure in SubSaharan Africa. The International Bank for Reconstruction and Development / The World Bank. Washington, DC; 2010.

Drèze J, Sen A. (eds.). The political economy of hunger. Oxford: Oxford University Press; 1990.

FAO. Comprehensive Africa agriculture development programme. New Partnership for Africa's Development (NEPAD). Available on: http://www.fao.org/docrep/005/Y6831E/Y6831E00.htm; 2002. visited on Saturday 09 July 2011. 
FAO. Twenty-fifth regional conference for Africa: urbanization and food security in SubSaharan Africa. Nairobi, Kenia; 2008.

FAO. Food security statistics. Available on: http://www.fao.org/economic/ess/food-securitystatistics/en/; 2009. Visited on Tuesday 13 October 2009, (Number of undernourished people)

Friends of the Earth International. Playing with hunger. The reality behind the shipment of GMOs as food aid. A publication of the FoEI GMO Programme. Amsterdam; 2003.

Goodland R. Environmental sustainability in agriculture: diet matters. Ecological Economics 1997;23:189-200.

IFC (International Finance Cooperation). Infrastructure in Africa. Available on: http://www.ifc.org/ifcext/africa.nsf/Content/Infrastructure; 2010. Visited on Saturday 24 June 2011.

Kamau J. We must guard against modified foods. Available on: http://allafrica.com/stories/200206100010.html; 2002. Visited on Tuesday 14 June 2011.

Knox PL, Marston SA. (eds.). Places and regions in global context. New Jersey: Pearson Prentice Hall; 2007.

Mason JB, Lotfi M, Dalmiya N, Sethuraman K, Deitchel M. The micronutrient report. Current progress and trends in the control of vitamin A, Iodine, and Iron deficiencies. Micronutrient Initiative; Ottawa, Canada; 2001.

Matz D, Ferenz M. Consensus-building processes in society and genetically modified organisms: the concept. In: SD. Omamo and K. von Grebmer (eds.). Biotechnology, agriculture, and food security in Southern Africa. Washington, D.C.; International Food Policy Research Institute:37-70.

MIT (Massachusetts Institute of Technology). Roads in Sub-Saharan Africa. Available on: http://12.000.scripts.mit.edu/mission2014/solutions/roads-in-sub-saharan-africa; 2011. Visited on Saturday 09 July 2011.

McMichael P. Contemporary contradictions of the global development project: geopolitics, global ecology and the 'development climate. Third World Quarterly 2009a;30(1):247-262.

McMichael P. A food regime genealogy. Journal of Peasant Studies 2009b;30(1): 139-169.

Morse S. GM crops and development. In: V Desai, and RB Potter (eds.): The companion to development studies, $2^{\text {nd }}$ edition, London: Hodder Education; 2008:170-176. 
Mugabe J. Keeping hunger at bay. Agricultural biotechnology and food production in SubSaharan Africa. Technology Policy Brief 5, Nairobi: African Technology Policy Studies Network (ATPS); 2003.

Olembo N. Intellectual property rights policy. In: SD. Omamo and K. von Grebmer (eds.). Biotechnology, agriculture, and food security in Southern Africa. Washington, D.C.; International Food Policy Research Institute:173-186.

Otsuka K, Kalirajan, KP. Rice Green Revolution in Asia and its transferability to Africa: an introduction. The Developing Economies 2006;XLIV-2:107-22.

Paarlberg R. Are genetically modified (GM) crops a commercial risk for Africa? International Journal for Technology and Globalisation 2006;2(1-2):81-92.

Pelletier D. Food safety and consumer choice policy. In: SD. Omamo and K. von Grebmer (eds.). Biotechnology, agriculture, and food security in Southern Africa. Washington, D.C.; International Food Policy Research Institute:113-156.

Perkins JH. The Rockefeller Foundation and the Green Revolution, 1941-1956. Agriculture and Human Values 1990;7(3-4):6-18.

Prasad G. Improving access to energy in sub-Saharan Africa. Current Opinion in Environmental Sustainability 2011;3:1-6.

Saini GR. Green revolution and the distribution of farm incomes. Economic and Political Weekly 1976;11(13):A17-A22.

Shah A. Food aid as dumping. Available on: http://www.globalissues.org/article/10/food-aidas-dumping; 2005. Visited on Friday 24 June 2011.

Smirzai A. The dynamics of socio-economic development: an introduction. Cambridge: Cambridge University Press; 2005.

Trewavas AJ. The population/biodiversity paradox. Agricultural efficiency to save wilderness. Plant Physiology 2001;125:174-179.

Thompson CB. Africa: Green Revolution or rainbow evolution? Review of African Political Economy 2007;34(113):562-565.

Thomson J. Genetically modified crops - good or bad for Africa? Biologist 2007;54(3):129133.

Ushewokunze-Obatolu U. Biosafety policy. In: SD. Omamo and K. von Grebmer (eds.). Biotechnology, agriculture, and food security in Southern Africa. Washington, D.C.; International Food Policy Research Institute:157-172.

van Straaten P. Rocks for crops. Agrominerals of sub-Saharan Africa. Nairobi: ICRAF; 2002. 
von Braun J. Food insecurity, hunger and malnutrition: necessary policy and technology changes. New Biotechnology 2010;27(5):449-452.

Weeks JR. (ed.). Population, an introduction to concepts and issues. Belmont: Wadsworth Thomson Learning; 2005.

Wu F, Butz WP. (eds.). The future of genetically modified crops; lessons from the Green Revolution. Santa Monica: RAND cooperation; 2004. 